\title{
The specificity of crossing air borders by civil and state aircraft
}

\author{
Karolina Julia Helnarska ${ }^{1}$, Jacek Krawczyk ${ }^{*}, 2$, and Lukasz Korytek ${ }^{1}$ \\ ${ }^{1}$ University Jan Dlugosz in Czestochowa, Faculty of Philology and History, Poland \\ ${ }^{2}$ Dymińska 3/24, 01-519 Warsaw, Poland
}

\begin{abstract}
The article presents issues related to the legal regulations regarding the crossing of airspace boundaries by civil and state aircraft. Additionally, there are also described differences in the formal requirements for the conduct of civil and state aircraft operations. In addition, there have been described difficulties in the implementation of tasks for state aviation, which may have a negative impact on the protection of military contingents abroad, outflows outside the country, security of visits by state representatives and international cooperation. The process of acquiring permission to cross the air border by a state aircraft is also presented, which is much more complicated than the requirements for civil aircraft, the limitations of which are related only to the weight of the aircraft, the purpose of the flight and the technical and operational capabilities of the machine. The following article will bring the process of obtaining diplomatic approvals for state aircraft flights. The rules and formal as well as legal principles that must be met to obtain diplomatic approval for the conduct of an aircraft operation by a state aircraft will be described.
\end{abstract}

\section{Introduction}

Based on the International Civil Aviation Convention signed on December 7, 1944. (OJ of June 26, 1959), hereinafter referred to as the Convention ${ }^{1}$; Contracting States recognize that each State has total and exclusive sovereignty over the airspace on its territory. In addition, the Convention specifies the definition of "territory", - the territory of each country is land and adjacent territorial waters, covered by sovereignty, mandate or protection of the state. The convention also defines nationality, country of registration = nationality. An aircraft can only be registered in one country, but registration may be transferred to another country. All aircrafts that will operate in international spaces must have the appropriate nationality and registration marks.

Accordingly, to cross the state border, you must obtain the appropriate permission issued by the competent state authorities. In the case of civil aircraft, it is the President of

\footnotetext{
${ }^{1}$ Convention - International Civil Aviation Convention signed on 7 December 1944. (OJ of 26 June 1959)
} 
the Civil Aviation Office, hereinafter referred to as the President of the Office, while in the case of military aircraft it is the Operational Commander of the Armed Forces ${ }^{2}$.

The convention defines the type of aircraft, due to the user and the purpose of the flight, while the Act of 3 July 2002 Aviation Law (Journal of Laws 2002 No. 130 item 1112 as amended) defines the type of aircraft, due to the entry of proper registration of the aircraft. The above is a cause of difficulties in the process of issuing diplomatic permits, due to discrepancies regarding the competent office in the country to which the decision to cross the state air border should be issued ${ }^{3}$.

Aircrafts are divided into two groups, civil and state, what is determined by the register in which the owner registers the aircraft. There are three registers in Polish legislation:

1. the register of civil ship kept by the President of the Office ${ }^{4}$,

2. the register of military aircraft kept by the Minister of National Defense ${ }^{5}$ and

3. the register of aircraft for law enforcement services maintained by the Minister competent for internal affairs ${ }^{6}$.

With reference to the article 2 paragraph 3 points a and b of the cited law, state airships are divided into military aircraft used by the Armed Forces of the Republic of Poland and aircrafts which serve public order used by the Border Guard, Police and State Fire Service ${ }^{7}$.

In accordance with the Convention, the entry of the state aircraft into the airspace of another state is possible after a special permission is granted and must be carried out in accordance with the terms of such permission, considering the safety of the air navigation of civil aircraft ${ }^{8}$.

Each state, using its sovereignty, may introduce regulations for foreign state aircraft that carry out air operations in their air spaces. Therefore, on the basis of aircraft performing aerial operations in airspace of other countries, ammunition and war equipment cannot be transported without the consent of the authorities of that state. Each country is obliged to establish regulations which governs the transport of hazardous materials and ICAO regulations. In addition, all countries have the right to introduce regulations and restrictions to ensure public order and transport safety over their territory. However, it should be done in such a way as not to restrict air transport and equipment as well as navigation systems on the aircraft necessary for the safety of air navigation.

Accordingly to the Convention, the State has sovereign supremacy over its airspace, so there is no obligation to issue diplomatic clearance. There are many reasons for not issuing such a permission from sympathizing or supporting the authorities or social groups in another country to dislike or default payment for a navigation or terminal service on the itinerary. In addition, the answer itself may be provided in a different way by firmly failing to give consent or avoiding sending a clear and legible answer. To sum up, state aircraft must have a diplomatic license from the competent state authorities to cross the state border, execute in their air space a transit flight or landing area and take off at a designated airport. Obtaining diplomatic consent is an extremely long and complicated process during which the legal regulations of all states along the route of flight and the current political and military situation must be taken into account.

\footnotetext{
${ }^{2}$ Rozporządzenie Ministra Obrony Narodowej z dnia 30 listopada 2016 r. zmieniające rozporządzenie w sprawie przekraczania granicy państwowej i lotów obcych wojskowych statków powietrznych w przestrzeni powietrznej Rzeczypospolitej Polskie (Dz.U. 2016 poz. 2120).

3 art. 3 Ustawy Prawo lotnicze z dnia 3 lipca 2002 r. (Dz. U. z 2017 r. poz. 959 i 1089 z póź. zm).

${ }^{4}$ Ibidem Art. 34 ust. 1

${ }^{5}$ Ibidem Art. 43 ust. 1

${ }^{6}$ Ibidem Art. 44 ust. 1

${ }^{7}$ Ibidem

${ }^{8}$ International Civil..., op.cit.
} 
On the other hand, the implementation of an aircraft operation consists of many factors such as weather conditions, operational condition of the aircraft, training of the flight crew and the availability of airports as well as airways.

\section{General rules of state border crossing by state aircraft}

According to the cited Convention, art. 3c., no State aircraft of a Contracting State may proceed over the territory of another State nor land over it without an authorization granted by special agreement or otherwise or in breach of the terms of that authorization ${ }^{9}$.

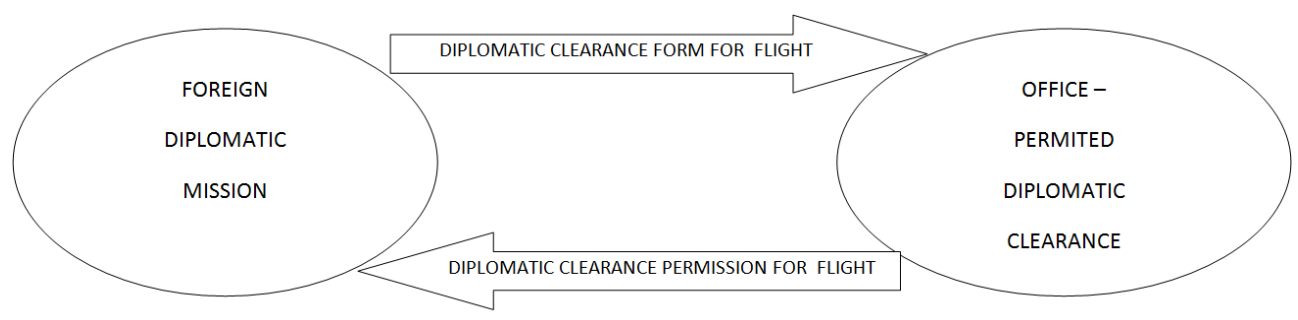

Fig. 1. Procedures for the issuance of diplomatic permits for entry of foreign military aircraft Source: Own elaboration

Representatives of diplomatic missions and representatives of countries accredited in the state along the state passage of a state aircraft apply for a diplomatic license to cross the state air border and perform air operations in the airspace of foreign states to the competent state authorities. Representatives of states issue or refuse to issue a diplomatic license in the form of a diplomatic note with a date enabling the conduct of an air operation or its cancellation if the formal issues have not been fully fulfilled.

In order to ensure the safety of airspace users in carrying out air operations and state security, on board of aircraft involved in international air navigation should be located:

- aircraft registration card,

- a certificate of airworthiness,

- a license for each crew member,

- travel diary,

- documentation for the radio station,

- passenger name list with entry and exit information,

- declaration of transported cargo.

The International Civil Aviation Organization provides the possibility for countries, organizations or institutions to introduce eight classes of airspace from A to $G$, in which flight operations according to IVR (Instrumental Flight Rules) and VFR (Visual Flight Rules) are allowed, depending on the type of air traffic services, which are exercised in a particular class of airspace. Airspace classes are published in AIP (Aeronautical Information Publication) and can be changed to adapt to the current requirements of airspace users via SUP and AIP according to AIRAC (Aeronautical Information Regulation And Control) or by NOTAM (Notice to Airman). Airspace users must comply with their requirements with the exception of the airspace above the high sea, whereby aircraft operations are allowed to be conducted by State aircraft according to the Due Regards principle, i.e. with respect to the other airspace users.

\footnotetext{
${ }^{9}$ International Civil..., op.cit.
} 


\section{Relations of entities and consequences affecting the process of issuing and obtaining diplomatic permits}

The implementation of operations by civil aircraft in the European Union takes place on the basis of a concession pursuant to Regulation (EC) No. 1008/2008 of the European Parliament and of the Council of 24 September 2008 on common rules for the operation of air services in the Community. The European carrier after obtaining a concession pursuant to art. 15 (2) of the above regulation does not have to have any additional permissions to cross the borders of EU member states. The license shall remain valid as long as the Community air carrier meets the requirements of the Regulation ${ }^{10}$.

To sum up, when obtaining concessions for air transport as a Community carrier, it is not required to obtain diplomatic consent for each crossing of airborne national borders.

Acquiring a diplomatic license for a state aircraft is a chain of interrelationships between flight planning, coordination and internal regulations of countries along the route. The proper functioning of all three elements translates into the implementation of the flight task at the planned time. If one of the elements fails, this results in the lack of a diplomatic license to perform air operations in foreign air spaces. The above statement is only a general thesis for the purposes of this article, as there may be many reasons for not issuing a diplomatic license.

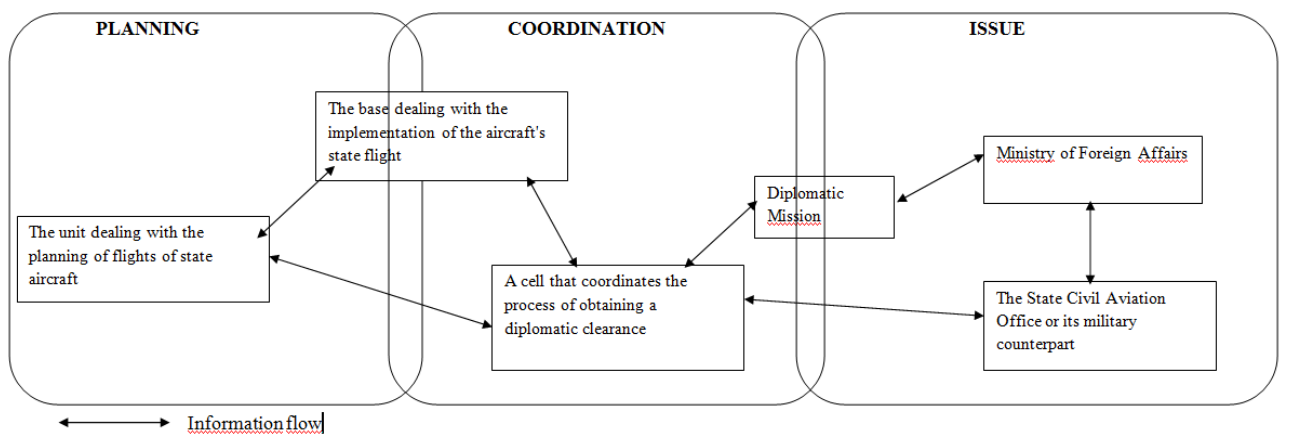

Fig. 2. Diagram of interrelations between flight planning, coordination and internal regulations of states along the state passage of an aircraft. Source: Own elaboration.

The diagram above illustrates the interrelationships between individual institutions involved in the process of completing an aerial task by a state aircraft. An efficient exchange of information between the entities concerned guarantees the smooth operation of the above system.

It should be noted that where the flight of an aircraft has HEAD status - "the status of an aircraft, military special air transport or other military aircraft with the most important person in a state on board during an official mission, assigned in accordance with applicable regulations ${ }^{11 "}$ is treated as preferential. In practice, this means that appropriate

\footnotetext{
${ }^{10}$ Regulation (EC) No 1008/2008 of the European Parliament and of the Council of 24 September 2008 on common rules for the operation of air services in the Community.

${ }^{11}$ DECISION No. 2 / MON OF THE MINISTRY OF NATIONAL DEFENSE of 4 January 2013 on the introduction of the "Instruction on the organization of flights marked HEAD status in the aviation of the Armed Forces of the Republic of Poland. HEAD status is given to flights performed as part of official missions, on aircraft, on board which there are:

1) President of the Republic of Poland;

2) the Speaker of the Parliament of the Republic of Poland;
} 
institutions in countries after the flight route issue diplomatic permits as a matter of urgency. In Polish legislation, such flights do not require a diplomatic license - art. 18a paragraph 3 point $1^{12}$. In connection with the above, all theses will apply to state aircraft with a different status than HEAD.

Each state along the state passage of a state aircraft has its own rules for issuing a diplomatic clearance. The above provisions differ from each other in many respects, among others, the number and type of documents required, the manner and timing of their transfer. Polish regulations regarding deadlines are set out in the Ordinance of the Minister of National Defense of November 30, 2016 amending the ordinance on crossing the state border and flights of foreign military aircraft in the airspace of the Republic of Poland and are presented as follows:

1. 2 working days prior to the planned flight of military aircraft without dangerous cargo or with dangerous goods;

2. 3 working days before the planned landing of military aircraft at international airports without dangerous cargo or with dangerous goods;

3. 3 working days before the planned landing of military aircraft belonging to the member states of the North Atlantic Treaty Organization at military airfields without dangerous cargo or with dangerous goods;

4. 10 working days prior to the planned landing of military aircraft not belonging to the member states of the North Atlantic Treaty Organization at military airfields without dangerous goods or with dangerous goods;

5. 3 working days before the planned landing of foreign civil aircraft carrying out tasks for the needs of the Armed Forces of the Republic of Poland in the field of transport of cargo or soldiers, officers of the Military Counterintelligence Service, Military Intelligence Service or Government Protection Bureau or military personnel for military airports, entered into the register of military airfields maintained by the Minister of National Defense ${ }^{13}$.

It should be noted that they have one common denominator. Failure to meet the above conditions results in the lack of a diplomatic license to cross the state air border and perform an air operation in the airspace of the state.

Considering a single state, there are number of reasons for not receiving a diplomatic license. The most common reason for not issuing a diplomatic license is not to provide the required by the authorities of the country of destination or of the route of the flight documents at the date specified by the state ${ }^{14}$.

Another reason may be the international situation in the region of operations, where state authorities do not allow air operations performed by state aircraft over their territory.

In addition, the internal situation of the state is an important factor in obtaining a diplomatic license. The refusal to issue a permit may be caused, for example, by important state ceremonies or the closure of airspace for air traffic by state aircraft.

3) the Speaker of the Senate of the Republic of Poland;

4) Chairman of the Council of Ministers;

5) persons reported through diplomatic channels to the office servicing the minister competent for foreign affairs, being the counterparts of persons referred to in points 1-4, from foreign countries.

Flights of the most important people in the state.

${ }^{12}$ The Act on the Protection of the State Border (Journal of Laws No. 78, item 461, as amended).

${ }^{13}$ Regulation of the Minister of National Defense of November 30, 2016 amending the ordinance on crossing the state border and flights of foreign military aircraft in the airspace of the Republic of Poland (Journal of Laws of 2016 item 2120);

${ }^{14}$ The deadline is the period counted on working days before the planned date of flight on which the state authorities should receive an application for issuing a diplomatic license. 
The state authorities do not issue diplomatic permits also for financial reasons, for example, not paying the air / navigational charges in the territory of a given country by the owner of a state aircraft or his tenant.

In order to avoid the above mentioned situations, the owner of a state aircraft or his tenant should plan flight operations in such a way that the required deadline for submitting requests for consent avoids dates of valid state and religious holidays. Appropriate planning of flights of state aircraft is the key to the effective implementation of aviation operations.

The internal regulations of the states provide shorter deadlines and a simplified procedure in the appendix when ${ }^{15}$ the state-owned aircraft have MEDEVAC (medical evacuation) or CASEVAC (casualty evacuation ${ }^{16}$ ) status prioritized. Usually, the dates and requirements for obtaining a diplomatic license for a flight of this status are much shorter.

It should be noted that there are situations in which, despite possession of a diplomatic license for a state aircraft flight, an aerial task cannot be performed due to the closure of airspace, e.g. in connection with state ceremonies. In this situation, the flight should be postponed until the airspace is opened. The transfer of flight is possible because the legal regulations of the states provide for the validity of diplomatic approvals not less than 72 hours from the planned implementation of the flight operation.

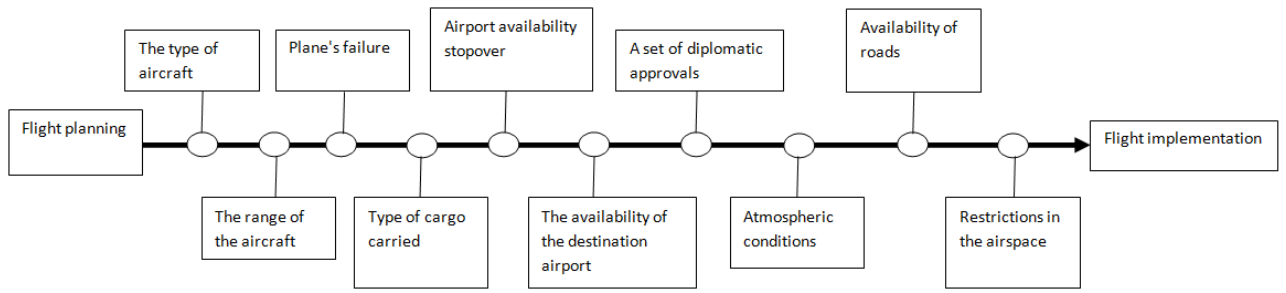

Fig. 3 Influence of factors on the performance of air operations of state aircraft in foreign air spaces. Source: Own elaboration.

Many factors contribute to the operation of a plane by a state aircraft (Fig. 3). They are interdependent interrelationships, which in the event of failure to meet one requirement result in the inability to perform the flight operation. Each element matters from the planning of the flight through the selection of the right aircraft, to the availability of airports and the completion itself. All elements are interrelated, so if one is not met the whole project will not be implemented.

In the event of an emergency situation which is not foreseen as a failure of the aircraft, a state aircraft should be sent with repaired parts. The quick acquisition of a diplomatic license mainly depends on the region in which the failure occurred. By generalizing a flight in the airspace of countries belonging to the European Union, it can take place within one or two working days and is treated as a sudden situation, and diplomatic permits are issued with priority without the time limits required by the authorities.

The situation is completely different when the flight must take place beyond the borders of the European Community. In African and Asian countries, the arrival of an aircraft with spare parts or repair personnel for an inoperative unit is treated as a normal flight and must meet all the requirements of States after the flight path, provided that it is a normal flight without hazardous materials or with hazardous materials and personnel technical on board.

To harmonize the border crossing requirements in airspace by military aircraft, the EDA $^{17}$ has initiated the creation of a technical agreement to define uniform rules on

\footnotetext{
${ }^{15}$ Except for flights with the HEAD status

${ }^{16}$ MEDEVAC- medical transport medyczny;

CASEVAC- transport from combat zone.

${ }^{17} \mathrm{https} / /$ www.eda.europa.eu/docs/default-source/documents/dic-ta.pdf
} 
diplomatic approvals for crossing state air borders in European countries by state aircraft. The document specifies uniform deadlines, procedures for military aircraft flights, and a DIC Form ${ }^{18}$ for all Signatory States of the Agreement. The number of countries ${ }^{19}$ that have joined the technical agreement is constantly increasing, and cooperation in issuing diplomatic approvals for state aircraft is simple, fast and clear. In addition, the European Defense Agency organizes training, analyzes the existing rules on issuing diplomatic permits and runs its own library to which signatories of the technical agreement have access.

\section{Summary}

The specification for obtaining and issuing permits for crossing air borders between states is different for civil and state aircraft.

Table 1. Similarities and differences in the performance of air operations by state and civil aircraft. Source: Own elaboration.

\begin{tabular}{|l|l|l|}
\hline Requirements & State aircraft & Civil aircraft \\
\hline Flight Plan & Required & $\begin{array}{l}\text { Required in Class C space and } \\
\text { when information and emergency } \\
\text { services are to be provided }\end{array}$ \\
\hline Diplomatic permission & $\begin{array}{l}\text { Required for crossing the state } \\
\text { border }\end{array}$ & Not required \\
\hline On-board documentation & Required & Required \\
\hline Landing at civil airports & $\begin{array}{l}\text { Possible after obtaining the } \\
\text { consent of the airport }\end{array}$ & $\begin{array}{l}\text { In accordance with the SLOTAMI } \\
\text { granted }\end{array}$ \\
\hline $\begin{array}{l}\text { Landing at military } \\
\text { airports }\end{array}$ & Landing after obtaining a PPR & Landing only at designated airports \\
\hline $\begin{array}{l}\text { Lot without required } \\
\text { permits }\end{array}$ & $\begin{array}{l}\text { A military aircraft can be shot } \\
\text { down }\end{array}$ & $\begin{array}{l}\text { It can be shot down when only } \\
\text { terrorists are on board }\end{array}$ \\
\hline $\begin{array}{l}\text { Flight speed limits in } \\
\text { airspace classes }\end{array}$ & No speed limits & $\begin{array}{l}\text { Limited to 250 kts (463 km / h) } \\
\text { below 10,000 ft }\end{array}$ \\
\hline $\begin{array}{l}\text { Performing flights in } \\
\text { unclassified space }\end{array}$ & Flight operation is possible & $\begin{array}{l}\text { Inability to perform an aerial } \\
\text { operation }\end{array}$ \\
\hline $\begin{array}{l}\text { Flights over international } \\
\text { waters }\end{array}$ & $\begin{array}{l}\text { Conducting air operations } \\
\text { contrary to the ICAO airspace } \\
\text { class }\end{array}$ & Accordingly to ICAO regulations \\
\hline
\end{tabular}

The basis for the civil operation of the aircraft is to comply with the requirements of the airspace class in which the aircraft operation is performed. The main factors which determine the performance of air operations in foreign airspace include the submission of a Flight Plan, provision of two-way radio communication in relation to the aircraft pilot with the air traffic services and possession of the necessary technical equipment of the aircraft.

The flight of a state aircraft each time requires obtaining diplomatic approval from the competent state authorities to perform an air operation in the airspace of a given country. The biggest obstacle is to keep the deadlines for submitting the required documents for granted diplomatic consent by state authorities, which results from the special nature of operations performed by state aircraft. Another obstacle is the need to meet the conditions received in diplomatic consent, such as the time of flight, the type of cargo carried and information about the aircraft.

\footnotetext{
${ }^{18}$ DIC Form - Diplomatic Application submitted to obtain a permit to cross the state air border.

${ }^{19}$ Currently, there are 17 countries in the Technical Agreement.
} 


\section{References}

[1] AIP Polska - Aeronaultical Information Publication - Poland (www.ais.pansa.pl/aip);

[2] Annex 11 to the Convention on International Civil Aviation. Air Traffic Services (Annex to Decree No. 12 of the President of the Civil Aviation Office of November 28, 2016);

[3] Annex 15 to the Convention on International Civil Aviation. Air Information Services (Annex to Decree No. 13 by the President of the Civil Aviation Office of November 28, 2016);

[4] Annex 2 to the Convention on International Civil Aviation. Air Traffic Regulations (Annex to the announcement No. 14 of the President of the Civil Aviation Office of November 28, 2016);

[5] Decision No. 2 / MON of the Minister of National Defense from January 4, 2013 regarding the introduction of the "Instruction on the organization of flights marked HEAD status in the aviation of the Armed Forces of the Republic of Poland" (Official Gazette of the Ministry of National Defense of 2013 item 4)

[6] International Civil Aviation Convention signed on December 7, 1944. (OJ of June 26, 1959);

[7] Regulation of the Minister of National Defense of November 30, 2016 amending the ordinance on crossing the state border and flights of foreign military aircraft in the airspace of the Republic of Poland (Journal of Laws of 2016 item 2120);

[8] REGULATION OF THE EUROPEAN PARLIAMENT AND OF THE COUNCIL (EC) No 1008/2008 of 24 September 2008 (Journal of Laws of the European Union of 31 October 2008 L293 / 3);

[9] The Act on the Protection of the State Border of October 12, 1990 (Journal of Laws of 2017, item 660);

[10] The Act of July 3, 2002. Aviation Law (Journal of Laws of 2013, item 1393, from 2014 item 768 of 2015 , item 978, 1221).

* corresponding author: jkkrawczyk2@gmail.com 